\title{
Pathways affect vegetation structure and composition in the Atlantic Forest in southeastern Brazil
}

\author{
Bruna Gonçalves da Silva ${ }^{*}$, Ana Carolina Devides Castello ${ }^{2}$, Ingrid Koch ${ }^{3}$ and Wesley Rodrigues Silva ${ }^{4}$
}

Received: November 15, 2016

Accepted: February 8, 2017

\begin{abstract}
Although impacts generated by gaps can affect vegetation, few studies have addressed these impacts in the Atlantic Forest. Our aim was to investigate the effects of pathways of varying widths on vegetation structure and composition, considering dispersal syndromes, diversity, life forms, successional categories and threatened and exotic species occurrence in the Atlantic Forest. We studied three pathways with widths of 2, 10 and $20 \mathrm{~m}$, intersecting a protected area in southeastern Brazil. To assess edge effects, plots were established adjacent to paths (edge) and $35 \mathrm{~m}$ from the edge (neighborhood), and in a control area without pathways. Wider pathways (10 and $20 \mathrm{~m}$ ) exhibited reduced tree height and diameter, high liana density, exotic species, and a high proportion of pioneer and anemochorous species. In conclusion, our results indicate that the vegetation structure of narrow pathways $(2 \mathrm{~m})$ is similar to the control area, and that wide linear gaps cause negative effects on vegetation and extend to a distance of at least 35 $\mathrm{m}$ into the forest interior. Considering that linear gaps generate permanent effects to vegetation and may affect other organisms, we suggest that these effects must be considered for successful management of protected areas, including planning and impact mitigation.
\end{abstract}

Keywords: Carlos Botelho State Park, conservation, linear gaps, plants, roads, trails

\section{Introduction}

Pathway construction amidst forests creates gaps that increase habitat fragmentation, one of the main threats to tropical forests (Gascon et al. 2000). Unlike natural forest gaps, anthropic linear gaps are practically immutable due to maintenance activities, imposing persistent effects on the conditions and resources of the forest nearby (Laurance et al. 2009). The effects of pathways relate to topography (e.g. earthmoving), soil conditions, microclimatic conditions, light exposure, which create distinct environments compared to the forest interior (Tabarelli et al. 1999; Webb et al. 1999;
Laurance et al. 2009), affecting habitat structure and species composition (Mantovani 2001; Enoki et al. 2012).

Tall trees and shade tolerant species usually inhabit old-growth tropical forest interiors (Liebsch et al. 2008). Environments with increased light availability create conditions for the colonization of early-successional species, normally wind-dispersed (Tabarelli et al. 1999; Laurance et al. 2009). The maintenance of these conditions over time and space allows the permanence of species associated with disturbed environments (Murcia 1995). Consequently, a permanent shift in plant community structure and composition might occur (Mantovani 2001).

\footnotetext{
${ }^{1}$ Programa de Pós-Graduação em Ecologia, Departamento de Biologia Animal, Universidade Estadual de Campinas, Rua Monteiro Lobato, 255, 13083-862, Campinas, SP, Brazil

${ }^{2}$ Programa de Pós-Graduação em Ciências Biológicas, Departamento de Botânica, Universidade Estadual Paulista Júlio de Mesquita Filho, campus Botucatu, Rubião Júnior, s/n, 18618-970, Botucatu, SP, Brazil

${ }^{3}$ Departamento de Biologia Vegetal, Instituto de Biologia, Universidade Estadual de Campinas, Rua Monteiro Lobato, 255, 13083-862, Campinas, SP, Brazil

${ }^{4}$ Departamento de Biologia Animal, Universidade Estadual de Campinas, Rua Monteiro Lobato, 255, 13083-862, Campinas, SP, Brazil
}

* Corresponding author: bgsilvab@gmail.com 
Several studies addressed the changes in vegetation structure and composition at the edges of linear forest gaps (Demir 2007; Enoki et al. 2012; Otto et al. 2013; Li et al. 2014) and just a few conducted in tropical forests focused on linear gaps caused by roads, gas pipelines and power lines (Reznik et al. 2012; Prieto et al. 2014; CoutoSantos et al. 2015), or pastures (Ribeiro et al. 2009a). In those studies, linear gaps affected the phenodynamics of animal dispersed plants (Reznik et al. 2012), tree species structure and richness (Ribeiro et al. 2009a; Couto-Santos et al. 2015), and proportion of pioneer species (Prieto et al. 2014). However, the extent to which the pathway width affects those forest attributes has never been properly assessed and understood.

The largest remaining portion of the Atlantic Forest, one of the biodiversity hotspots, lies in the Southeastern Brazil (Myers et al. 2000; Ribeiro et al. 2009b; Ribeiro et al. 2011a). Ecosystems within the Atlantic forest are being continuously degraded by illegal (e.g. poaching, selective logging), and legal (e.g. infrastructure installations such as roads, power lines, natural gas pipelines) impact vectors (Terborgh \& Schaik 2002; Ribeiro et al. 2011a). On the other hand, roads and pathways are part of the necessary infrastructures that allow the management and surveillance of any park, which are also sometimes used for educational, ecotourism and research purposes. Therefore, research on the impacts of gaps generated by pathways and their associated influence on vegetation integrity is a promising approach to guide a more critical discussion on the two sides of the conservation issue (effective management $\mathrm{x}$ effective protection), contributing for decisions on the landscape changes and management strategies along the Atlantic forest continuum.

In this study we investigate the impacts of pathways of varying widths on the vegetation structure and species composition in an Atlantic forest protected area in southeastern Brazil, through the assessment of different life forms, successional categories, threatened and exotic species and the predominance of dispersal syndromes. We hypothesize that impacts in the wider pathway are more pronounced than in areas where pathways are narrow or absent. These impacts differentially affect the vegetation structure and composition among pathways, with wider ones characterized by plants with low height and small diameter, a high proportion of pioneer and wind dispersed species, and the occurrence of exotic species.

\section{Materials and methods}

\section{Study site}

We conducted this study at Carlos Botelho State Park (CBSP), a 37,644.36 ha protected area, part of the Atlantic Forest continuum, located between $24^{\circ} 06^{\prime} 55^{\prime \prime}$ -

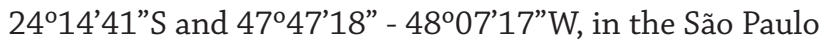
state, southeastern Brazil (Fig. 1A). Altitudinal amplitude within the CBSP ranges from 20 to $1000 \mathrm{~m}$. The climate is tropical, with mean annual temperature of $18{ }^{\circ} \mathrm{C}$, and annual precipitation between 1500 - $2200 \mathrm{~mm}$ (Ferraz \& Varjabedian 1999). The predominant vegetation type is Dense Ombrophilous Forest, which is divided into the following categories along the altitudinal gradient (Kronka et al. 2005): Lowland Dense Ombrophilous Forest (0 - 50 $\mathrm{m})$, Submontane Dense Ombrophilous Forest (51 - $500 \mathrm{~m}$ ) and Montane Dense Ombrophilous Forest (501 - 1500 m).

Pathways selected for sampling are located at an average altitude of $800 \mathrm{~m}$, in the Montane Dense Ombrophilous Forest (Fig. 1B). Several ecological aspects for plant communities (e.g. density, richness, diversity and species composition) are more affected in the first $35 \mathrm{~m}$ from forest edges (Rodrigues 1998). Thus, to include edge effects, we sampled at the pathways edge and $35 \mathrm{~m}$ from the edge (neighborhood) (Fig. 1C). We selected a single path per pathway type because in the same forest continuum and elevation there are no replicas for the pathway types. We collected data on the following pathway types: main road, secondary road and trail (Fig. 1B). In addition, we established a control area, reputedly close to a reference state of conservation (Fig. 1B) (SMA 2008). All sampled plots are distributed within the same forest matrix, climate, altitude, and are spatially close (minimum distance between plots within the same pathway $=200 \mathrm{~m}$ and between pathways $=600 \mathrm{~m}$ ). The control area is at least $1000 \mathrm{~m}$ away from the forest edge. Given the small spatial scale of the study, it is possible to assume that differences between plots are more related to direct effects of the pathways instead of purely spatial effects. The topography distribution of the plots encompassed mostly slopes, with some at hilltops and stream valleys, a similar pattern across all survey pathways.

\section{Types of pathway}

The main road within the CBSP is a dirt road of $112 \mathrm{~km}$ long (named SP-139) and about $20 \mathrm{~m}$ wide that intersects a total of $33 \mathrm{~km}$ of the state park area, with a completely open canopy (Fig. 2A). The secondary road is a dirt road approximately $12 \mathrm{~km}$ long and mostly $10 \mathrm{~m}$ wide, with the canopy covered at some points (Fig. 2B). The trail is approximately $4.5 \mathrm{~km}, 2.0 \mathrm{~m}$ wide, with the canopy covered along its total extension (Fig. 2C). The control area is representative of the mature forest occurring in most of the park (Fig. 2D), without apparent anthropic influence (SMA 2008).

\section{Sampling Design}

In each pathway we a priori selected a stretch of $1400 \mathrm{~m}$ along its total extension that was parallel to the pathway. We disregarded the first $500 \mathrm{~m}$ of each pathway in order 


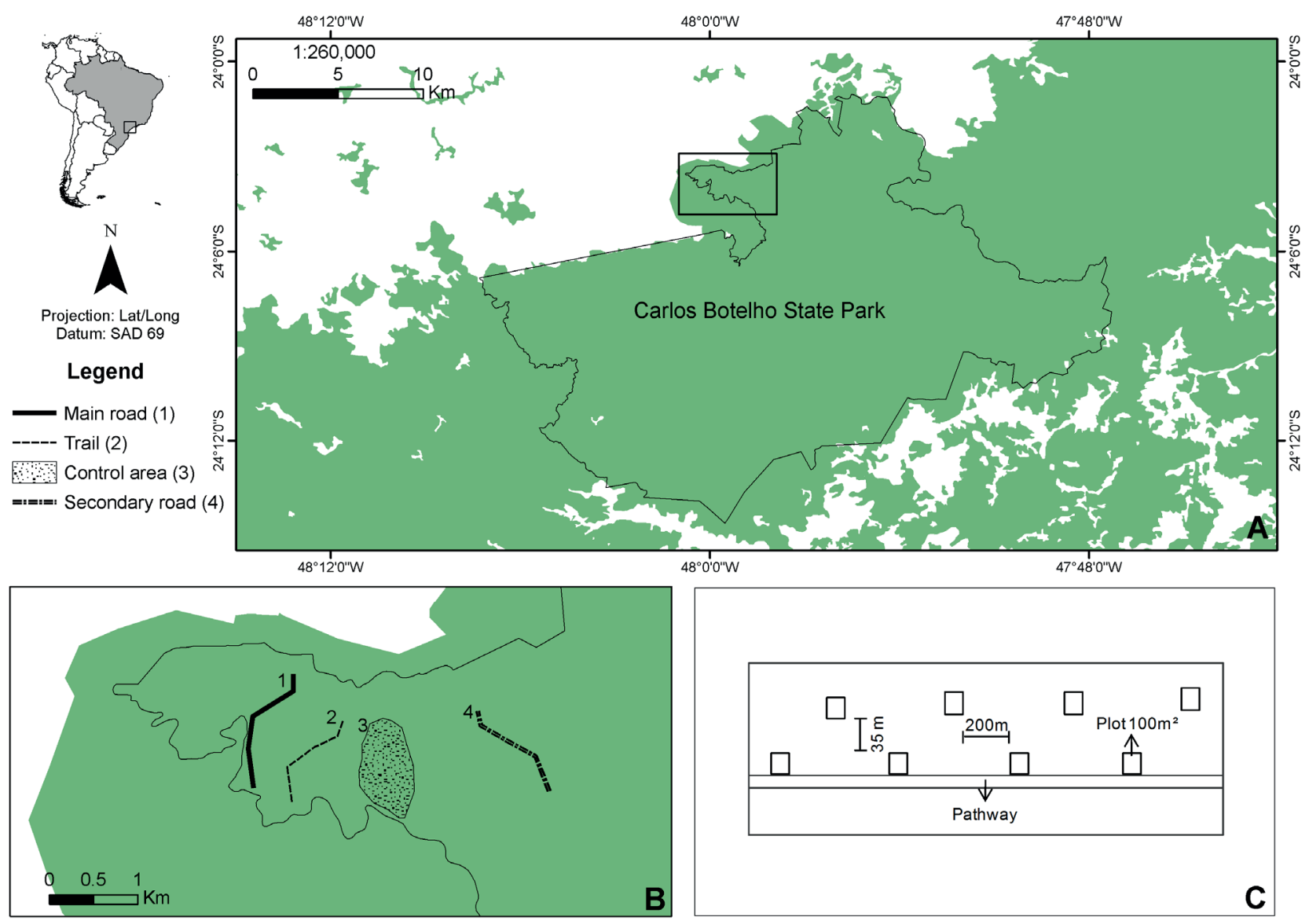

Figure 1. A. Location of Carlos Botelho State Park, SE Brazil. B. Situation of the pathways and control area sampled - 1: main road, 2: trail, 3: control area, 4: secondary road. C. Distribution of plots along the pathway (four adjacent to the pathway - edge - and four $35 \mathrm{~m}$ towards the forest interior - neighborhood).

to minimize forest edge effects, and only achieve pathway edge effects. Along each selected stretch eight $10 \times 10 \mathrm{~m}$ sampling plots were alternately set: four adjacent to the path (edge) and four $35 \mathrm{~m}$ from the edge (neighborhood) (Fig. 1B). Plots were separated at least by $200 \mathrm{~m}$ of each other along the path to secure the independence of sampling units (Dias \& Couto 2005; Lenza et al. 2011) (Fig. 1B). At the control area we set the eight plots in the same manner, except that there was no pathway. We used the pathways width (2,10 and $20 \mathrm{~m})$, named here as "type of pathway", as a proxy of edge effects. In this design, the "type of pathway" (including control area) and "distance to edge" ( 0 and 35 $\mathrm{m})$ are considered as treatments.

\section{Vegetation survey}

Vegetation structure and abundance - We recorded the following variables from individuals with diameter at breast height $(D B H) \geq 3.18 \mathrm{~cm}$ : total height, $D B H$ and tree crown diameter (Durigan 2003). Total height (measured from ground) and tree crown diameter (by estimating the canopy radius) were visually estimated using a $3 \mathrm{~m}$ stick as a parameter. The same person made all measurements. Based on total height, individuals were classified into three strata: high understory (1.5 - $5 \mathrm{~m}$ ), intermediate level (5.1 - $11 \mathrm{~m}$ ) and canopy (above $11 \mathrm{~m}$ ). We also measured the low understory density of each plot by counting the number of individuals with $10-100 \mathrm{~cm}$ in height $(D B H$ was always lower than $3.18 \mathrm{~cm}$ ), in four sub-plots of $1 \times 1$ $\mathrm{m}$ at sampling points randomly assigned within each $10 \mathrm{x}$ $10 \mathrm{~m}$ plot. Subplots were only installed for measuring the understory density, where individuals were counted but not identified. We excluded bamboo species (Merostachys sp.) from low understory density surveys, because they were considered as a separate variable (see below).

Abundance of epiphytes, vines (considering the herbaceous or woody) and bamboos (Merostachys sp.) in each plot was also recorded and classified in categories according to the percentage of the plot area cover. For epiphytes and vines we considered the categories low (<20\%), medium (20 - $50 \%$ ) and high (>50\%), and for bamboos we established lower abundance thresholds (10\% - low, 10-30\% medium and $>30 \%$ - high). We recorded the presence of exotic species inside plots and along the pathways. This 


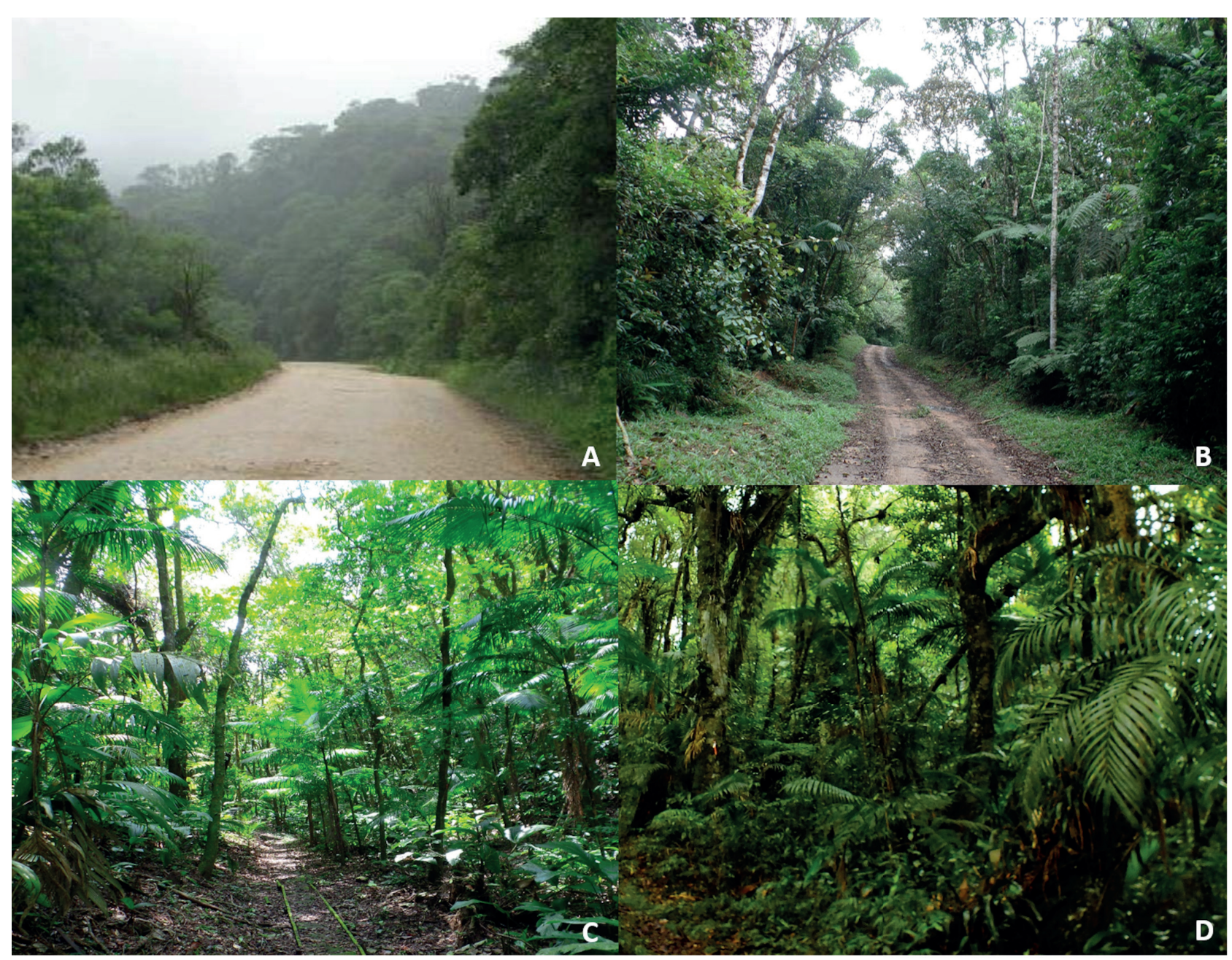

Figure 2. Sampling areas at Carlos Botelho State Park, São Paulo state, SE Brazil. Different pathways used as treatments - A: main road (20 m of width), B: secondary road (10 $\mathrm{m}$ of width), C: trail (2 $\mathrm{m}$ of width), D: control area.

methodology was adapted from the Brazilian Ministry of Environment Resolution No. 01/94 (CONAMA 2015).

Canopy openness in each plot was measured using hemispherical photographs (Frazer et al. 2001), taken with a Nikon Coolpix 4500 camera with a fish-eye FC-E8 lens. We positioned the camera, with the aid of a tripod, at an approximate $60 \mathrm{~cm}$ height, at the centre of each plot. Photographs were taken in cloudy days to avoid over exposure to direct sunlight, which may influence image analysis (Frazer et al. 2001). We converted the resulting images in black and white colours in ImageJ software (2015). The canopy openness was estimated based on white pixels, which correspond to the percentage of gaps.

Vegetation composition - We considered the following variables to assess vegetation composition in each plot: life forms, diversity, successional categories, threatened and exotic species occurrence and predominance of dispersal syndromes. We identified and tagged all individuals with $D B H \geq 3.18 \mathrm{~cm}$. Plant species were identified by collecting individual reproductive branches under SISBIO (\#23627-1) and IBAMA (\#4968681) collection permission. Identification was based on the literature and consultation to botanists. Vouchers were deposited at the Universidade Estadual de Campinas herbarium (UEC).

We grouped species according to two general successional categories: pioneer, including pioneer and early secondary, and non-pioneer, including late secondary and climax species (São Paulo 2008; Ronquim \& Torresan 2011; Lingner et al. 2013). Dispersal syndromes were identified as zoochorous, anemochorous and autochorous following Pijl (1970). In addition, we considered the species' level of threat, according to the list of threatened flora of São Paulo state (São Paulo 2008), the red book of Brazilian flora (Martinelli \& Moraes 2013) and IUCN's list of threatened flora (IUCN 2015). The species list was organized according to the taxonomical arrangement adopted by the Angiosperm Phylogeny Group IV (APG 2016). Species names were cross-checked with the List of Species of the Brazilian Flora (2015). 


\section{Data analyses}

Vegetation structure and abundance - Plots were considered as independent sampling units. We applied a two-way ANOVAs for tree crown diameter, $D B H$ and total height (considering mean values for plots), canopy openness for plot and percentage of individuals per stratum (high understory, intermediate level and canopy) and low understory density as response variables and "type of pathway" and "distance to edge" as predictors. The assumptions of normality and homogeneity of variance were verified using the Shapiro-Wilk test and confirmed visually in graphic analyses. When a significant ANOVA was obtained $(P<0.01)$, a post hoc HSD Tukey test was used to investigate differences between treatments, where $P<0.05$ was considered significant.

Vegetation composition - We tested the difference in species composition for "type of pathway" and "distance to edge", considering abundance and richness, using the permutational multivariate analysis of variance (Permanova; Anderson 2001) ( $P$ < 0.01 was considered significant). We used the "adonis" function of the $\mathrm{R}$ vegan package with Bray-Curtis distances and 10,000 permutations. In order to verify general tendencies of variation in vegetation composition, we performed an ordination analysis with non-metric multidimensional scaling (NMDS; Minchin 1987). We adopted this approach to better identify and interpret similarities between treatments. All analyses were performed in the R environment ( $\mathrm{R}$ Core Team 2015).

We performed a diversity profile analysis, because it enables comparisons, as opposed to description of diversity indices only. With $\alpha=1$, it is equivalent to Shannon's diversity index $\left(H^{\prime}\right)$, and $\alpha=2$, it is equivalent to Simpson's diversity index $(D) ; \alpha=0$ corresponds to richness values in different pathways. Therefore, we were able to compare treatments according to evenness and richness. These analyses were conducted using PAST (Hammer et al. 2001).

To evaluate differences in the proportion of zoochorous and pioneers species between the "type of pathway" and "distance to edge" we used generalized linear models with a binomial distribution. Significance of the factors was assessed by means of a Chi-squared Analysis of Deviance $(P<0.01$ was considered significant). The analyses were carried out in the R statistical software (R Core Team 2015).

\section{Results}

\section{Vegetation structure and abundance}

We sampled 1019 individual trees $(D B H \geq 3.18 \mathrm{~cm})$ and 2302 individuals in the low understory (10 - 100 $\mathrm{cm}, D B H<3.18 \mathrm{~cm}$ ). Mean crown diameter, mean $D B H$, mean total height, canopy openness, tree percentage per stratum (except intermediate stratum) and low understory density were affected by type of pathway (Tab. 1). For those variables, trail and control areas were similar, but they significantly differed from main and secondary roads, which were also similar to each other (Tab. 2). The trail and control area had higher values for $D B H$, tree crown diameter, tree height and number of individuals in the canopy stratum, whereas main and secondary roads had higher values for canopy openness and number of individuals in the high and low understory (Tab. 2).

We found low epiphytes abundance, and low/medium herbaceous vines abundance for main road. In main and secondary roads, abundance of both epiphytes and herbaceous vines ranged from low to high. For trail and control area, epiphytes abundance was medium to high, and abundance of herbaceous vines was low, with predominance of woody vines (i.e. lianas). Bamboo (Merostachys sp.) clumps predominated in some points of the main and secondary roads (low, medium and high abundance), while in the control and trail areas bamboo abundance was low. In the main and secondary roads we recorded Urochloa sp. (=Brachiaria sp.), an exotic species, and the invasive Pteridium sp.. Additionally, we observed Citrus $\mathrm{x}$ limon and Eucalyptus sp. present along the main and secondary roads outside the sampled plots.

\section{Vegetation composition}

Only the type of pathway influenced plant composition (PERMANOVA; type of pathway: $F_{3,25}=1.78, p<0.001$ ), while distance to the edge $\left(F_{1,25}=1.12, p=0.283\right)$ and their interaction $\left(F_{2,25}=1.08, p=0.995\right)$ were not significant. The ordination analysis (NMDS), final stress: 0.22 , was consistent with results generated by PERMANOVA, and plots surveyed in the main road were grouped and separated from plots in the control area and trail, highlighting a marked difference between these areas. There was a distribution of points along axis 1 going from the wider pathways to the control area. However, no pattern was observed along axis 2. Data of the secondary road plots data formed an undefined grouping pattern (Fig. 3).

The control area and secondary road presented equal number of species ( $84 \mathrm{spp}$.), followed by trail ( $80 \mathrm{spp}$.) and main road (76 spp.). The control area and main road had the highest number of exclusive species (27 spp.), followed by secondary road ( $24 \mathrm{spp}$.) and trail (17 spp.). Secondary road and trail shared a high number of species (43 spp.). In contrast, control area and main road had the lowest number of shared species. Only 17 species were sampled in all areas (Tab. S1 in supplementary material). Of the total species (178 spp.), 15 are listed in threatened flora lists (São Paulo 2008; Martinelli \& Moraes 2013; IUCN 2015). Six species are listed as vulnerable and five as endangered; four are listed in more than one list of threatened flora (Tab. S1 in supplementary material). Main road was the pathway with the lowest number of threatened species. The diversity 


\section{Pathways affect vegetation structure and composition in the Atlantic Forest in southeastern Brazil}

Table 1. ANOVA results. Variables of vegetation structure considering type of pathway, distance to edge (35 $\mathrm{m})$ and interaction, at Carlos Botelho State Park - SP, Brazil. DBH - diameter at breast height. $P<0.01$ was considered significant.

\begin{tabular}{|c|c|c|c|c|}
\hline & & $D F$ & $F$ & $p$ \\
\hline \multirow{4}{*}{ Tree crown diameter* } & Type of pathway (TP) & 3 & 18.64 & $<0.0001$ \\
\hline & Distance to edge (DE) & 1 & 0.007 & 0.934 \\
\hline & $\mathrm{TP} \times \mathrm{DE}$ & 2 & 0.714 & 0.499 \\
\hline & Residuals & 25 & & \\
\hline \multirow{4}{*}{$\mathrm{DBH}(\mathrm{cm})^{*}$} & Type of pathway & 3 & 13.09 & $<0.0001$ \\
\hline & Distance to edge & 1 & 0.57 & 0.457 \\
\hline & $\mathrm{TP} \times \mathrm{DE}$ & 2 & 0.72 & 0.493 \\
\hline & Residuals & 25 & & \\
\hline \multirow{4}{*}{ Total height $(\mathrm{m})^{*}$} & Type of pathway & 3 & 29.94 & $<0.0001$ \\
\hline & Distance to edge & 1 & 0.91 & 0.349 \\
\hline & $\mathrm{TP} \times \mathrm{DE}$ & 2 & 0.57 & 0.571 \\
\hline & Residuals & 25 & & \\
\hline \multirow{4}{*}{ Canopy openness } & Type of pathway & 3 & 13.34 & $<0.0001$ \\
\hline & Distance to edge & 1 & 1.53 & 0.227 \\
\hline & $\mathrm{TP} \times \mathrm{DE}$ & 2 & 0.91 & 0.415 \\
\hline & Residuals & 25 & & \\
\hline \multirow{4}{*}{ Percentage of trees surveyed on the high-understory $(1.5-5 \mathrm{~m})$} & Type of pathway & 3 & 23.02 & $<0.0001$ \\
\hline & Distance to edge & 1 & 0.163 & 0.69 \\
\hline & $\mathrm{TP} \times \mathrm{DE}$ & 2 & 0.527 & 0.597 \\
\hline & Residuals & 25 & & \\
\hline \multirow{4}{*}{ Percentage of trees surveyed on the intermediate level (5.1- $11 \mathrm{~m})$} & Type of pathway & 3 & 2.3 & 0.101 \\
\hline & Distance to edge & 1 & 0.04 & 0.835 \\
\hline & $\mathrm{TP} \times \mathrm{DE}$ & 2 & 0.34 & 0.714 \\
\hline & Residuals & 25 & & \\
\hline \multirow{4}{*}{ Percentage of trees surveyed on the canopy level (above $11 \mathrm{~m}$ ) } & Type of pathway & 3 & 10.49 & 0.0001 \\
\hline & Distance to edge & 1 & 0.03 & 0.859 \\
\hline & $\mathrm{TP} \times \mathrm{DE}$ & 2 & 0.02 & 0.974 \\
\hline & Residuals & 25 & & \\
\hline \multirow{4}{*}{ Low-understory $(10 \mathrm{~cm}-100 \mathrm{~cm} \text { height })^{*}$} & Type of pathway & 3 & 6.41 & 0.002 \\
\hline & Distance to edge & 1 & 0.28 & 0.596 \\
\hline & $\mathrm{TP} \times \mathrm{DE}$ & 2 & 0.08 & 0.923 \\
\hline & Residuals & 25 & & \\
\hline
\end{tabular}

* = Mean values for plot

Table 2. HSD Tukey's test. Variables of vegetation structure among type of pathway at Carlos Botelho State Park - SP, Brazil. DBH - diameter at breast height. $P<0.05$ was considered significant.

\begin{tabular}{|l|c|c|c|c|}
\hline & Main road & Secondary road & Trail & Control area \\
\hline Tree crown diameter* & $1.77 \pm 0.62^{\mathrm{a}}$ & $1.55 \pm 0.13^{\mathrm{a}}$ & $2.98 \pm 0.43^{\mathrm{b}}$ & $2.77 \pm 0.48^{\mathrm{b}}$ \\
\hline $\mathrm{DBH}(\mathrm{cm})^{*}$ & $8.34 \pm 0.96^{\mathrm{a}}$ & $9.35 \pm 1.30^{\mathrm{a}}$ & $12.37 \pm 1.51^{\mathrm{b}}$ & $12.62 \pm 2.44^{\mathrm{b}}$ \\
\hline Total height $(\mathrm{m})^{*}$ & $6.04 \pm 1.18^{\mathrm{a}}$ & $6.61 \pm 1.33^{\mathrm{a}}$ & $10.69 \pm 1.23^{\mathrm{b}}$ & $10.58 \pm 1.33^{\mathrm{b}}$ \\
\hline Canopy openness & $12.87 \pm 1.41^{\mathrm{a}}$ & $11.67 \pm 1.49^{\mathrm{a}}$ & $9.31 \pm 1.23^{\mathrm{b}}$ & $9.15 \pm 1.53^{\mathrm{b}}$ \\
\hline Percentage of trees surveyed on the high-understory $(1.5-5 \mathrm{~m})$ & $50.96^{\mathrm{a}}$ & $43.88^{\mathrm{a}}$ & $10.47^{\mathrm{b}}$ & $10.33^{\mathrm{b}}$ \\
\hline Percentage of trees surveyed on the intermediate level $(5.1-11 \mathrm{~m})$ & $40.32^{\mathrm{a}}$ & $42.61^{\mathrm{a}}$ & $32.19^{\mathrm{a}}$ & $53.99^{\mathrm{a}}$ \\
\hline Percentage of trees surveyed on the canopy level (above $11 \mathrm{~m})$ & $8.7^{\mathrm{a}}$ & $13.5^{\mathrm{a}}$ & $25.13^{\mathrm{b}}$ & $36.15^{\mathrm{b}}$ \\
\hline Low-understory $(10 \mathrm{~cm}-100 \mathrm{~cm}$ height) & $24.43 \pm 9.42^{\mathrm{a}}$ & $21.17 \pm 9.35^{\mathrm{a}}$ & $11.37 \pm 2.48^{\mathrm{b}}$ & $12.25 \pm 3.00^{\mathrm{b}}$ \\
\hline Total number of trees with $\mathrm{DBH} \geq 3.18 \mathrm{~cm}$ & 310 & 237 & 259 & 213 \\
\hline
\end{tabular}

${ }^{a, b}=$ Variables significantly different according to HSD Tukey test $\mathrm{p}<0.05$

$*$ = Mean values for plot

profile analysis demonstrated that the diversity index is similar among the areas (Fig. 4). However, when assigned more weight to evenness $(\alpha=2)$ main road plots and trail edge plots had the lowest values, and when assigned more weight to richness secondary road had high values (Fig. 4).

Zoochorous species predominated in all areas, representing more than $70 \%$ of the total species number (Fig. 5A). There was no difference in zoochorous species 


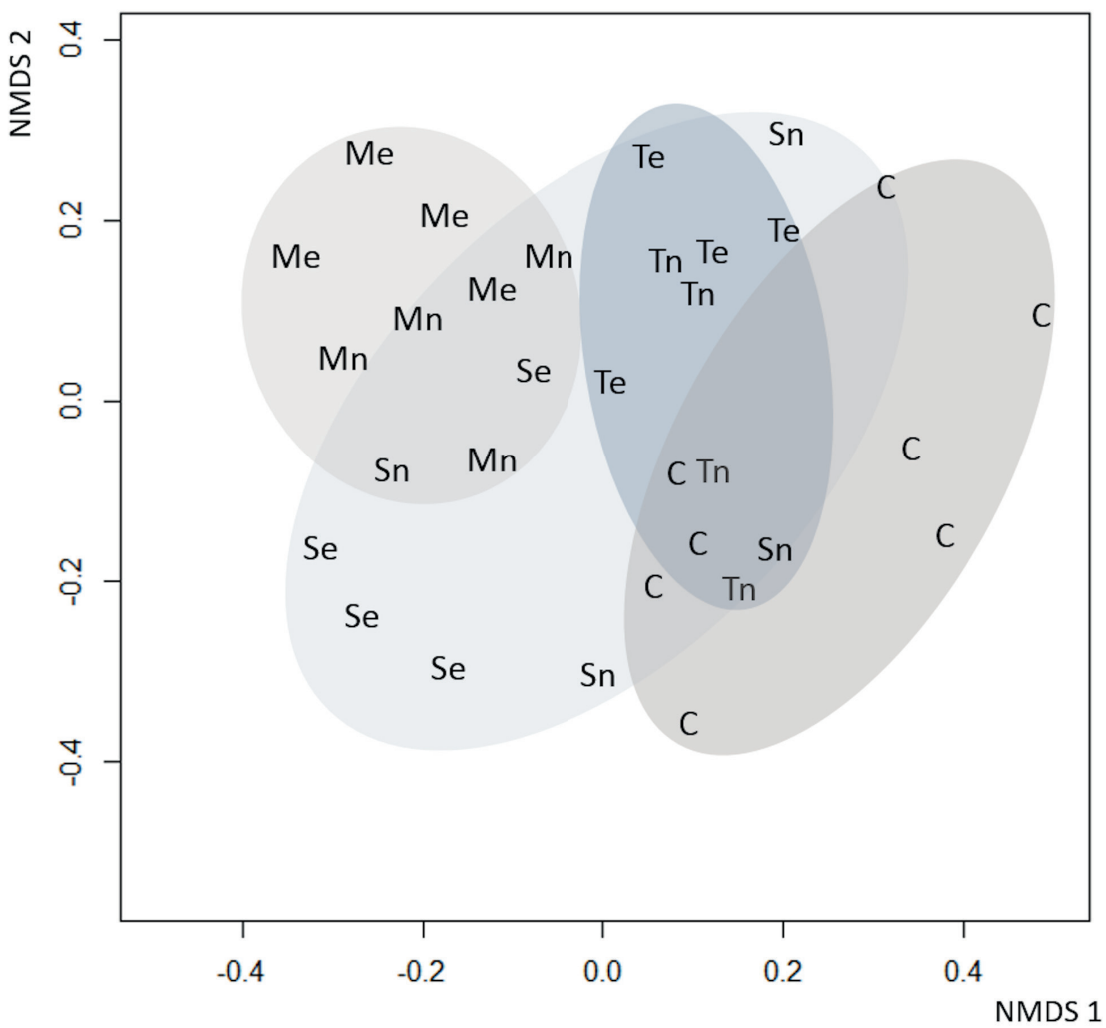

Figure 3. Scaling analysis (nMDS) of plant community among surveyed plots of treatments type of pathway and distance to edge in Carlos Botelho State Park, SP, Brazil. M: main road, S: secondary road, T: trail (e - edge, n - neighborhood), C: control area (nMDS, Final stress: 0.22).

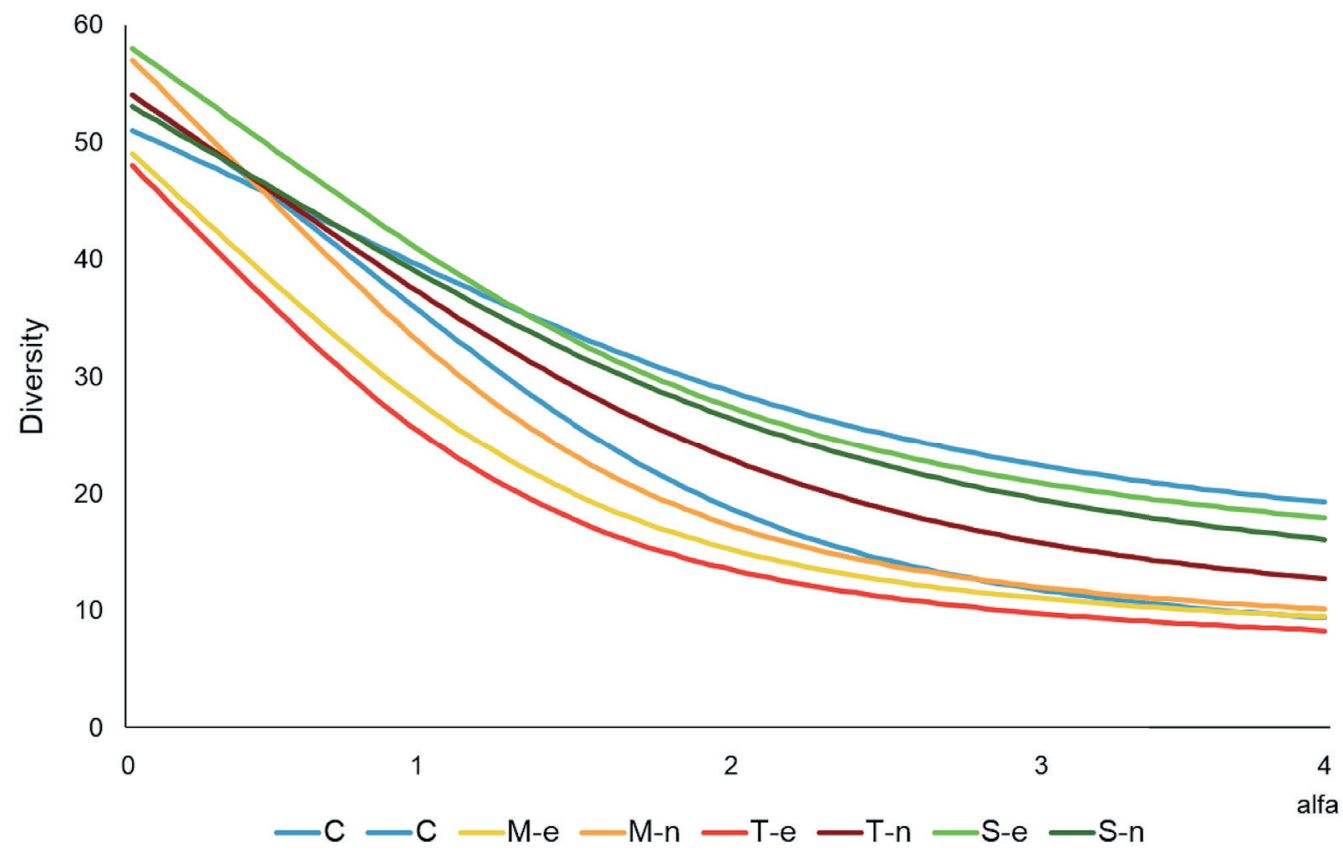

Figure 4. Diversity profile of plant community among pathways at Carlos Botelho State Park, SP, Brazil. M: main road, S: secondary road, T: trail, (e - edge, $\mathrm{n}$ - neighborhood), C: control area. $\alpha=1$, it is equivalent to Shannon's diversity index $\left(H^{\prime}\right)$, and $\alpha=2$, it is equivalent to Simpson's diversity index $(D) ; \alpha=0$ corresponds to richness values. Please see the PDF version for color reference. 
Table 3. Results for generalized linear model for proportion of dispersal syndromes: zoochorous vs. non-zoochorous (anemochorous plus autochorous) species and individuals; and proportion of successional categories: pioneer vs. non-pioneer species and individuals, considering "type of pathway", "distance to edge" and interaction, at Carlos Botelho State Park - SP, Brazil. P 0.01 was considered significant.

\begin{tabular}{|l|c|c|}
\hline \multicolumn{1}{|c|}{ Species } & Dispersal syndromes & \\
\hline
\end{tabular}

predominance among types of pathway and distance to edge (Tab. 3, Fig. 5A). The number of individuals, on the other hand, was smaller in the main road edge compared to neighborhood and other pathways and control area (Tab. 3, Fig. 5B).

The proportion of pioneer species and individuals was different for type of pathway and distance to edge (Tab. 3 , Fig. 5C, D). Wider pathways presented higher values when compared to the trail and control area (Tab. 3, Fig. $5 C, D)$. The edge plots of wider pathways had the highest values when compared to their own neighborhood plots (Fig. 5C, D).

\section{Discussion}

Changes in vegetation were detectable beyond the edges in wider (10 and $20 \mathrm{~m}$ ) pathways, at least $35 \mathrm{~m}$ towards the forest interior. Different widths can determine the degree of microclimatic changes in the edge zone of a pathway (Pohlman et al. 2007). Light availability, high temperatures, low relative humidity, variation in soil nutrient availability and sediment runoff are variables that change according to the characteristics of linear gaps (Reid \& Dunne 1984; Denslow 1987). Edges of wide pathways are more exposed to those factors when compared to narrow pathways, and can modify both the vegetation structure and the successional process in their vicinities (Goosem 1997). The distribution of plant species in tropical forests reflects different specific tolerances to drought, shade, and nutrient stress (Sterck et al. 2006; Engelbrecht et al. 2007; Baltzer \& Thomas 2010), implying that species are at least partially separated for different resource niches within a local community (Kraft \& Ackerly 2010; Sterck et al. 2014).

Species composition differed in pathways with different widths. The control area and the narrow pathway (trail) exhibited similar species composition, but differed from the wider pathway (main road). Plots along the $10 \mathrm{~m}$-width secondary road varied widely in species composition. The secondary road had half the width of the main road and canopy connection occurs in some points along its extension. This characteristic can promote high habitat heterogeneity and contribute to mixed species composition. Shade-tolerant species occurring in secondary road plots (e.g. Micropholis crassipedicellata, Ocotea odorifera and Myrcia eugeniopsoides) were also found in trail and control plots, but pioneer species (e.g. Tibouchina pulchra and Miconia cabucu) occurred mostly in main road plots. Thus, the high species diversity in the secondary road may be explained by a combination of species with different ecological requirements (Allouche et al. 2012), corroborating the intermediate disturbance hypothesis (Connel 1978; Molino \& Sabatier 2001). The low diversity in trail can be probably related to the selective logging that occurred during the extractive period (near the 40's) of charcoal production (SMA 2008), as indicated by the presence of some charcoal ovens along the trail (SMA 2008).

A wide linear gap such as the main road (20 m) may disturb microclimate conditions and resource availability for plants, affecting the species distribution and eventually 
Bruna Gonçalves da Silva, Ana Carolina Devides Castello,

Ingrid Koch and Wesley Rodrigues Silva
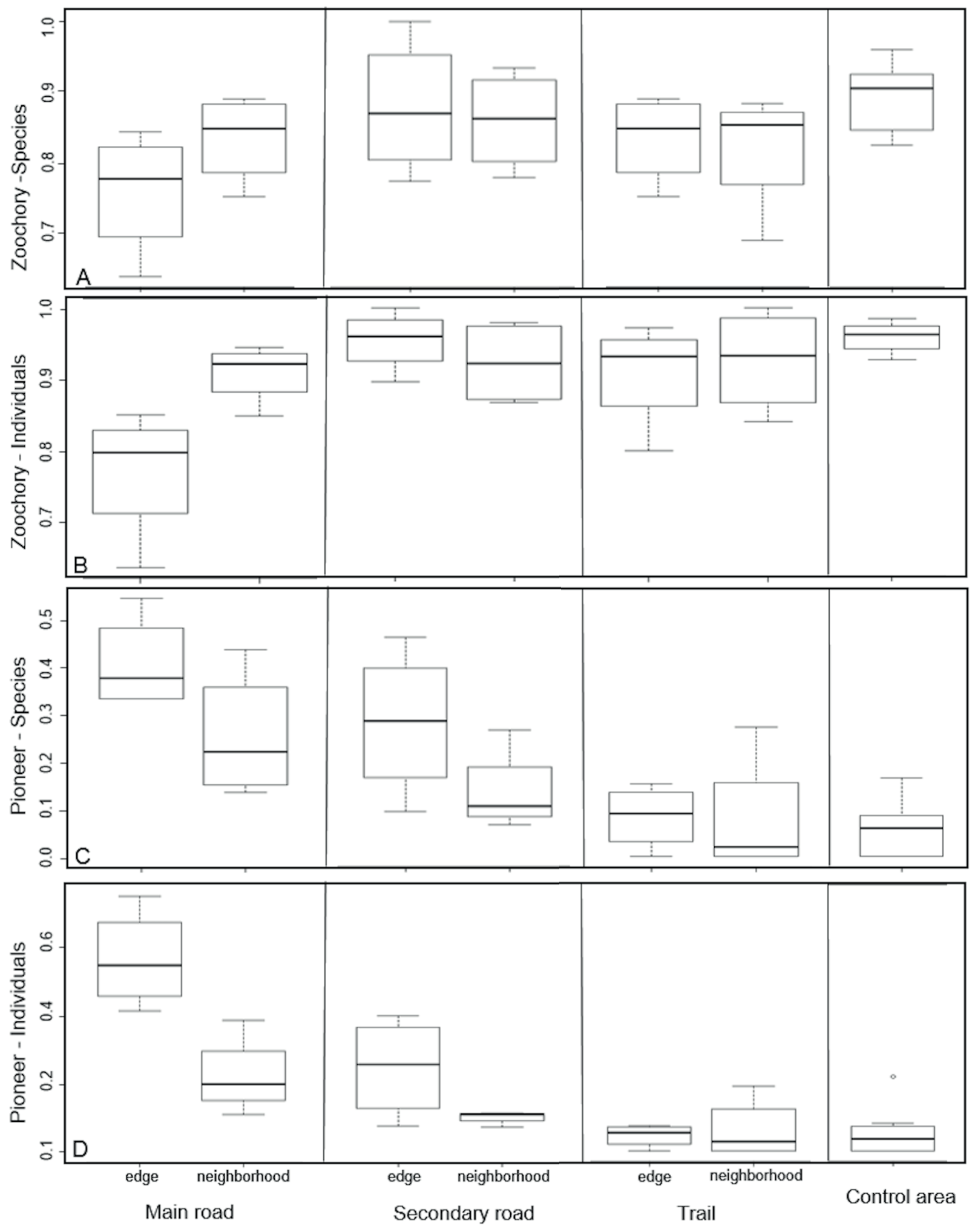

Figure 5. Proportion of dispersal syndromes - zoochorous vs. non-zoochorous (anemochorous plus autochorous) species and individuals; and proportion of successional categories: pioneer vs. non-pioneer species and individuals among "type of pathway" and "distance to edge" at Carlos Botelho State Park, SP, Brazil. The box-plots are displaying the median, the first and third quartile, and the maximum and minimum values of the data sets. A: Zoochorous species, B: Zoochorous individuals, C: Pioneer species, D: Pioneer individuals. 
causing differences in the vegetation structure and composition between the edges and their inner adjacent areas (Hartshorn 1980; Sterck et al. 2014). Recruitment of generalist species can be facilitated by a wide pathway gap, which would benefit from highly variable ecological conditions found at the edge of the main road (Forman \& Alexander 1998), resulting in species dominance (Denslow 1980), as demonstrated by the low evenness found in the main road. An increase in $10 \mathrm{~m}$ between the secondary and main road widths can be sufficient to determine differences in species composition, which emphasizes the importance of the gap size in the structuring of local plant communities (Denslow 1980; Zhu et al. 2014).

The predominance of species of different successional groups also depends on the gap size and the environmental conditions prevailing at the pathway edges (Denslow 1980), as verified for pioneer species, which have a positive relationship with gap size (Denslow 1980; Laurance et al. 2009). Shade intolerant pioneer species usually establish from the seed bank that existed prior to clearing or from subsequent recruitment (Tabarelli \& Peres 2002). When a linear gap is established in a forested area, microclimatic conditions are inevitably altered, which allows pioneer species germination and/or seed dispersal (Webb et al. 1999). On the other hand, non-pioneer species are much less abundant and are prone to death at edges (Tabarelli \& Peres 2002).

Wider pathways benefit anemochorous species because the aerodynamic design of their propagules enable them to be easily wind-transported for long distances in open environments (Howe \& Smallwood 1982; Jara-Guerrero et al. 2011). Changes in the frequency of dispersal strategies are a result of favorable habitat conditions and disperser activity (wind vs. vertebrate dispersal) coupled with specific life forms (shrubs vs. trees) and the species frequency in these groups through successional stages (Tabarelli \& Peres 2002). Accordingly, the wider pathway was characterized by a low frequency of zoochorous and a high density of anemochorous species. Gap size also determines the abundance of shrubs and small trees, since these life forms have greater densities in large rather than in small gaps (Zhu et al. 2014), as demonstrated by the higher densities of individuals smaller than $1 \mathrm{~m}$ height in the wider pathways.

Atlantic Forest threatened species with restricted distributions were also affected by pathway width, with lower numbers occurring in the wider pathway. The exception was Euterpe edulis, a dominant palm species in undisturbed areas of the Atlantic forest (Guilherme et al. 2004), which, contrary to our expectations, was among the most abundant species in all pathways. Possibly, the high survival rates of juvenile in gaps, compared to areas with dense canopy cover, may explain this unexpected pattern (Nakazono et al. 2001; Ribeiro et al. 2011b).

Vine abundance is also positively related to increases in linear gaps (Laurance et al. 2001; Bataghin et al. 2010).
High abundance of vines at forest edges results from their demand for intense light exposure and the presence of slender trees that provide support for their fixation (Putz 1984). On the other hand, epiphytes are more sensitive to microclimate variations (Hietz 1998), require tall trees as substrate, and are therefore negatively related to linear gap width (Gonçalves \& Waechter 2002; Wolf 2005). Not surprisingly, we found low abundance of epiphytes in areas intersected by wide pathways.

Intense management and traffic favor dispersal of exotic species along pathways (Dar et al. 2015), which is the case in our study, mainly at the main road. Despite the low traffic in the secondary road inside CBSP, exotic species were also recorded for this pathway, suggesting that even light traffic can promote the dispersal of exotic species. Moreover, the traffic-mediated dispersal of exotic species overcome competition with native plants, as many exotic species can withstand extreme conditions, like high light exposure, and succeed in colonising and establishing at the edges of pathways (Dar et al. 2015).

Plant communities with high number of individuals with small diameter and height were more frequent in the pathway edges but not in the control area, which indicates a typical initial regeneration phase (Guariguata \& Ostertag 2001; Couto-Santos et al. 2015). This condition was probably set well before the park creation (between 40's and 70's), with the implantation of the pathways, and remained stable over time due to path maintenance.

In tropical forests, areas adjacent to linear gaps are characterized by low species richness, high proportion of pioneers and anemochorous plants and presence of exotic species, as reported in this study and others (Ribeiro et al. 2009a; Reznik et al. 2012; Prieto et al. 2014). We also found that pathway width influences the nearby vegetation as much as its presence. Therefore, the impacts of pathways on the vegetation and, subsequently, on their associated fauna should be carefully considered for conservation and management purposes (Dewalt et al. 2003; Watson et al. 2004). Unfortunately, despite under state protection, our study area will probably continue to suffer impacts, because the roads are permanent. Additionally, modifications promoted by linear gaps may change over time according to the adopted management decisions and actions (Pickering et al. 2010; Müllerová et al. 2011), jeopardizing the status and distribution of several native plant species, as well as the control of the exotic ones, mostly in the wider pathways.

In conclusion, our study highlights that pathways wider than $10 \mathrm{~m}$ intersecting native forest areas negatively affect the vegetation structure and species composition, modifying the predominance of life forms and the (distribution/ proportion) of dispersal syndromes, with consequences for the successional categories, threatened species, besides increasing the occurrence of exotic species. These changes are permanent, interrupt the process of species turnover in ecological succession, and increase the intensity of 


\section{Bruna Gonçalves da Silva, Ana Carolina Devides Castello, Ingrid Koch and Wesley Rodrigues Silva}

effects according to the pathway width. We expect that changes in the vegetation should also influence the resource availability and habitat use by the fauna (Restrepo et al. 1999; Dewalt et al. 2003; Watson et al. 2004). Our study stresses the importance of assessing the trade-offs between the consequences for conservation and the necessities of management of Atlantic Forest protect areas crossed by different kinds of pathways.

\section{Acknowledgements}

The authors thank Fundação de Amparo à Pesquisa do Estado de São Paulo (FAPESP), for providing financial support (Grant 2013/11175-6); Instituto Florestal do Estado de São Paulo for collection permits; Fiorella F. M. Capelo and Marcelo Monge for helping with specimens identification; Leonardo Ré Jorge for statistical assistance, comments and suggestions; Alexander Vicente Christianini for comments and suggestions; Cristiane Patrícia Zaniratto, Eric Yasuo Kataoka, João de Deus Vidal Júnior and Mario Alejandro Marin Uribe for assistance with field work.

\section{References}

Allouche O, Kalyuzhny M, Moreno-Rueda G, Pizarro M, Kadmon R. 2012. Area-heterogeneity tradeoff and the diversity of ecological communities. Proceedings of the National Academy of Sciences 109: 17495-17500.

Anderson MJ. 2001. A new method for non-parametric multivariate analysis of variance. Austral Ecology 26: 32-46.

APG. 2016. An update of the Angiosperm Phylogeny Group classification for the orders and families of flowering plants: APG IV. Botanical Journal of the Linnean Society 181: 1-20.

Baltzer JL, Thomas SC. 2010. A second dimension to the leaf economics spectrum predicts edaphic habitat association in a Tropical Forest. PLoS One 5: e13163. doi:10.1371/journal.pone.0013163

Bataghin FA, Barros F, Pires JSR. 2010. Distribuição da comunidade de epífitas vasculares em sítios sob diferentes graus de perturbação na Floresta Nacional de Ipanema, São Paulo, Brasil. Revista Brasileira de Botânica 33: 501-512.

CONAMA - Conselho Nacional do Meio Ambiente. 2015. Resolução no. 1/1994. Define vegetação primária e secundária nos estágios pioneiro, inicial e avançado de regeneração da Mata Atlântica, afim de orientar os procedimentos de licenciamento de exploração da vegetação nativa no Estado de São Paulo. 〈https://www.conama.gov.br>. 01 Oct. 2015.

Connell J. 1978. Diversity in tropical rain forests and coral reefs. Science 199: 1302-1310

Couto-Santos APL, Conceição AA, Funch LS. 2015. The role of temporal scale in linear edge effects on a submontane Atlantic forest arboreal community. Acta Botanica Brasilica 29: 190-197.

Dar PA, Reshi ZA, Shah MA. 2015. Roads act as corridors for the spread of alien plant species in the mountainous regions: A case study of Kashmir Valley, India. Tropical Ecology 56: 183-190.

Demir M. 2007. Impacts, management and functional planning criterion of forest road network system in Turkey. Transportation Research Part A: Policy and Practice 41: 56-68.

Denslow JS. 1980. Gap partitioning among tropical rainforest trees. Biotropica 12: 47-55

Denslow JS. 1987. Tropical rainforest gaps and tree species diversity. Annual Review of Ecology, Evolution, and Systematics 18: 431-451.

Dewalt SJ, Maliakal SK, Denslow JS. 2003. Changes in vegetation structure and composition along a tropical forest chronosequence: implications for wildlife. Forest Ecology and Management 182: 139-151.
Dias AC, Couto HTZ. 2005. Comparação de métodos de amostragem na Floresta Ombrófila Densa - Parque Estadual Carlos Botelho/SP-Brasil. Revista do Instituto Florestal 17: 63-72.

Durigan G. 2003. Métodos para análise de vegetação arbórea. In: Cullen Jr L, Rudran R, Valladares-Padua C. (orgs.) Métodos de estudos em biologia da conservação e manejo da vida Silvestre. Curitiba, Editora UFPR. p. 455-479.

Engelbrecht BMJ, Comita LS, Condit R, et al. 2007. Drought sensitivity shapes species distribution patterns in tropical forests. Nature 447: 80-82.

Enoki T, Kusumoto B, Igarashi S, Tsuji K. 2012. Stand structure and plant species occurrence in forest edge habitat along different aged roads on Okinawa Island, southwestern Japan. Journal of Forest Research 19: 97-104.

Ferraz LPM, Varjabedian R. 1999. Evolução histórica da implantação e síntese das informações disponíveis sobre o Parque Estadual Carlos Botelho. São Paulo, Secretaria do Meio Ambiente/Instituto Florestal. Forman RTT, Alexander LE. 1998. Roads and their major ecological effects. Annual Review of Ecology, Evolution, and Systematics 29: 207-231.

Frazer GW, Fournier RA, Trofymow JA, Hall RJ. 2001. A comparison of digital and film fisheye photography for analysis of forest canopy structure and gap light transmission. Agricultural and Forest Meteorology 109: 249-263.

Gascon C, Williamson GB, Fonseca GAB. 2000. Receding forest edges and vanishing reserves. Science 288: 1356-1358.

Gonçalves CN, Waechter JL. 2002. Epífitos vasculares sobre espécimes de Ficus organensis isoladas no norte da planície costeira do Rio Grande do Sul: padrões de abundância e distribuição. Acta Botanica Brasilica 16: 429-441.

Goosem M. 1997. Internal Fragmentation: The effects of roads, highways, and powerline clearings on movements and mortality of Rainforest vertebrates. In: Laurance WF, Bierregaard Jr RO. (eds.). Tropical Forest Remnants. Chicago, University of Chicago Press. p. 241-255.

Guariguata MR, Ostertag R. 2001. Neotropical secondary forest succession: Changes in structural and functional characteristics. Forest Ecology and Management 148: 185-206.

Guilherme FAG, Morellato LPC, Assis MA. 2004. Horizontal and vertical tree community structure in a lowland atlantic rain forest, southeastern Brazil. Revista Brasileira de Botânica 27: 725-737.

Hammer Ø, Harper DAT, Ryan PD. 2001. Paleontological statistics software package for education and data analysis. Palaeontologia Electronica 4: 9-18.

Hartshorn GS. 1980. Neotropical forest dynamics. Biotropica 12: 23-30.

Hietz P. 1998. Diversity and conservation of epiphytes in a changing environment. Pure Applied Chemistry 70: 23-27.

Howe HF, Smallwood J. 1982. Ecology of seed dispersal. Annual Review of Ecology, Evolution, and Systematics 13: 201-208.

ImageJ. 2015. Imagine Processing and Analysis in Java. <https://imagej. nih.gov/ij/>. 01 Jul. 2015.

IUCN. 2015. The IUCN red list of threatened species. <http://www. iucnredlist.org/>. 01 Oct. 2015.

Jara-Guerrero A, Cruz M, Méndez M. 2011. Seed dispersal spectrum of woody species in South Ecuadorian Dry Forests: Environmental correlates and the effect of considering species abundance. Biotropica 43: 722-730.

Kraft JB, Ackerly DD. 2010. Functional trait and phylogenetic tests of community assembly across spatial scales in an Amazonian forest. Ecological Monographs 80: 401-422.

Kronka FJN, Nalon MA, Matsukuma CK, et al. 2005. Inventário florestal da vegetação natural do Estado de São Paulo. São Paulo, Secretaria do Meio Ambiente/Instituto Florestal.

Laurance WF, Albernaz AKM, Costa C. 2001. Is deforestation accelerating in the Brazilian Amazon? Environmental Conservation 28: 305-311.

Laurance WF, Goosem M, Laurance SGW. 2009. Impacts of roads and linear clearings on tropical forests. Trends in Ecology \& Evolution 24: 659-669.

Lenza E, Pinto JRR, Pinto AS, Maracahipes L, Bruziguessi ER. 2011. Comparação da vegetação arbustivo-arbórea de uma área de cerrado rupestre na Chapada dos Veadeiros, Goiás, e áreas de cerrado sentido restrito do Bioma Cerrado. Revista Brasileira de Botânica 34: 247-259. 


\section{Pathways affect vegetation structure and composition in the Atlantic Forest in southeastern Brazil}

Li Y, Yu J, Ning K, Du S, Han G, Qu F. 2014. Ecological effects of roads on the plant diversity of coastal wetland in the Yellow River Delta. Science World Journal 2014: 1-8.

Liebsch D, Marques MCM, Goldenberg R. 2008. How long does the Atlantic Rain Forest take to recover after a disturbance? Changes in species composition and ecological features during secondary succession. Biological Conservation 141: 1717-1725.

Lingner DV, Schorn LA, Vibrans AC, et al. 2013. Fitossociologia do componente arbóreo/arbustivo da Floresta Ombrófila Densa no estado de Santa Catarina. In: Vibrans AC, Sevegnari L, Gasper AL, Ligner DV. (eds.) Inventário Florístico Florestal de Santa Catarina. Blumenau, Editora da FURB. p. 159-200.

List of Species of the Brazilian Flora .2015. List of Species of the Brazilian Flora. <http://floradobrasil.jbrj.gov.br/>. 01 Oct. 2015.

Mantovani W. 2001. A paisagem dinâmica. In: Leonel C. (org.) Intervales. São Paulo, Secretaria do Meio Ambiente. p. 81-91.

Martinelli G, Moraes M. 2013. Livro vermelho da flora do Brasil. Rio de Janeiro, Andrea Jakobsson/Instituto de Pesquisas Jardim Botânico do Rio de Janeiro.

Minchin PR. 1987. An evaluation of the relative robustness of techniques for ecological ordination. Vegetatio 69: 89-107.

Molino JF, Sabatier D. 2001. Tree diversity in Tropical Rain Forests: A Validation of the Intermediate Disturbance Hypothesis. Science 294: 1702-1704

Müllerová J, Vítková M, Vítek O. 2011. The impacts of road and walking trails upon adjacent vegetation: Effects of road building materials on species composition in a nutrient poor environment. Science of the Total Environment 409: 3839-3849.

Murcia C. 1995. Edge effects in fragmented forests: implications for conservation. Tree 10: 58-62.

Myers N, Mittermeier RA, Mittermeier CG, Fonseca, GA, Kent J. 2000. Biodiversity hotspots for conservation priorities. Nature 403: 853-8.

Nakazono EM, Costa MC, Futatsugi K, Paulilo MTS. 2001. Crescimento inicial de Euterpe edulis Mart. em diferentes regimes de luz. Revista Brasileira de Botânica 24: 173-179.

Otto R, Arteaga MA, Delgado JD, Arévalo JR, Blandino C, FernándezPalacios JM. 2013. Road edge effect and elevation patterns of native and alien plants on an oceanic island Tenerife, Canary Islands. Folia Geobotanica 49: 1-18.

Pickering CM, Hill W, Newsome D, Leung YF. 2010. Comparing hiking, mountain biking and horse riding impacts on vegetation and soils in Australia and the United States of America. Journal of Environmental Management 91: 551-562.

Pijl L. 1970. Principles of dispersal in higher plants. Verlag Berlin Heidelberg, Springer.

Pohlman CL, Turton SM, Goosem M. 2007. Edge effects of linear canopy openings on Tropical Rain Forest understory microclimate. Biotropica 39: 62-71.

Prieto PV, Sansevero JBB, Garbin ML, Braga JMA, Rodrigues PJFP. 2014. Edge effects of linear canopy openings on understory communities in a lowland Atlantic tropical forest. Applied Vegetation Science 17: 121-128.

Putz FE. 1984. The Natural History of Lianas on Barro Colorado Island. Ecology 65: 1713-1724.

R Core Team. 2015. R: A Language and Environmental for Statistical Computing. <https://www.r-project.org/>. 01 Oct. 2015.

Reid LM, Dunne T. 1984. Sediment production from forest road surfaces. Water Resources Research 20: 1753-176.

Restrepo C, Gomez N, Heredia S. 1999. Anthropogenic edges, treefall gaps, and fruit-frugivore interactions in a Neotropical Montane Forest. Ecology 80: 668-685.
Reznik G, Pires JPDA, Freitas L. 2012. Efeito de bordas lineares na fenologia de espécies arbóreas zoocóricas em um remanescente de Mata Atlântica. Acta Botanica Brasilica 26: 65-73.

Ribeiro MC, Martensen AC, Metzger JP, Tabarelli M, Scarano F, Fortin MJ. 2011a. The Brazilian Atlantic Forest: a shrinking biodiversity hotspot. In: Zachos FE, Habel JC. (eds.) Biodiversity Hotspots: Distribution and Protection of Conservation Priority Areas. Verlag Berlin Heidelberg, Springer. p. 405-434.

Ribeiro MC, Metzger JP, Martensen AC, Ponzoni FJ, Hirota, MM. 2009b. The Brazilian Atlantic Forest: How much is left and how is the remaining forest distributed? Implications for conservation. Biological Conservation 142: 1141-1153.

Ribeiro MT, Nunes F, Santos FAM. 2009a. Tree structure and richness in an Atlantic forest fragment: distance from anthropogenic and natural edges. Revista Árvore 33: 1123-1132.

Ribeiro TM, Martins S, Lana VM, Silva K. 2011b. Sobrevivência e crescimento inicial de plântulas de Euterpe edulis Mart. transplantadas para clareiras e sub-bosque em uma Floresta Estacional Semidecidual, em Viçosa, MG. Revista Árvore 35: 1219-1226.

Rodrigues E. 1998. Edge effects on the regeneration of forest fragments in North Paraná. PhD Thesis, Harvard University, Cambridge, MA.

Ronquim CC, Torresan FE. 2011. Avaliação da sustentabilidade e planejamento ambiental em propriedade do setor silvicultural. <http:// ainfo.cnptia.embrapa.br/digital/bitstream/item/122959/1/4451. pdf $>.01$ Oct. 2015.

São Paulo E. 2008. Resolução SMA - 8, de 8.03.2007. Listagem das espécies arbóreas e indicação de sua ocorrência natural nos biomas/ecossistemas e regiões ecológicas do Estado de São Paulo, com a classificação sucessional e a categoria de ameaça de extinção. São Paulo, SMA.

SMA - Secretaria do Meio Ambiente do Estado de São Paulo. 2008. Plano de manejo do Parque Estadual Carlos Botelho. <http://fflorestal. sp.gov.br/planos-de-manejo/planos-de-manejo-planos-concluidos/> . 01 Oct. 2015.

Sterck FJ, Poorter L, Schieving F. 2006. Leaf traits determine the growthsurvival trade-off across Rain Forest tree species. The American Naturalist 167: 758-765.

Sterck F, Markesteijn L, Toledo M, Schieving F, Poorter L. 2014. Sapling performance along resource gradients drives tree species distributions within and across tropical forests. Ecology 95: 2514-2525.

Tabarelli M, Peres CA. 2002. Abiotic and vertebrate seed dispersal in the Brazilian Atlantic forest: Implications for forest regeneration. Biological Conservation 106: 165-176.

Tabarelli M, Mantovani W, Peres CA. 1999. Effects of habitat fragmentation on plant guild structure in the montane Atlantic forest of southeastern Brazil. Biological Conservation 9: 119-127.

Terborgh J, Schaik C. 2002. Por que o mundo necessita de parques. In: Terborgh J, Schaik C, Davenport L, Rao M. (orgs.) Tornando os parques eficientes: estratégias para a conservação da natureza nos trópicos. Curitiba, Editora da UFPR e Fundação O Boticário. p. 25-36.

Watson JEM, Whittaker RJ, Dawson TP. 2004. Habitat structure and proximity to forest edge affect the abundance and distribution of forest-dependent birds in tropical coastal forests of southeastern Madagascar. Biological Conservation 120: 315-331.

Webb EL, Stanfield BJ, Jensen ML. 1999. Effects of topography on rainforest tree community structure and diversity in American Samoa, and implications for frugivore and nectarivore populations. Journal of Biogeography 26: 887-897.

Wolf JHD. 2005. The response of epiphytes to anthropogenic disturbance of pine-oak forests in the highlands of Chiapas, Mexico. Forest Ecology and Management 212: 376-39.

Zhu J, Lu D, Zhang W. 2014. Effects of gaps on regeneration of woody plants: a meta-analysis. Journal of Forest Research 25: 501-510. 